
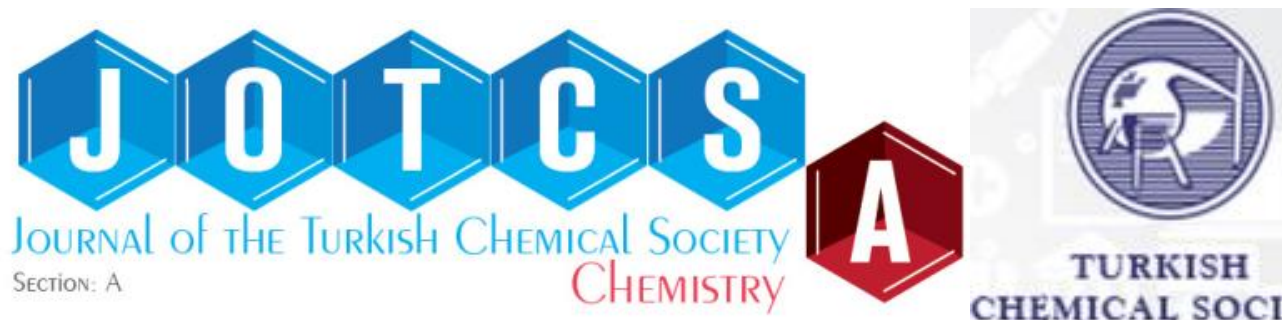

TURKISH

CHEMICAL SOCIETY

\title{
METAL-ORGANIC FRAMEWORKS (MOFS) DERIVED FROM CARBOXYLATE LIGAND AS POTENTIAL MATERIALS FOR REMEDIATION OF Cd(II) AND Pb(II) FROM AQUEOUS SOLUTION
}

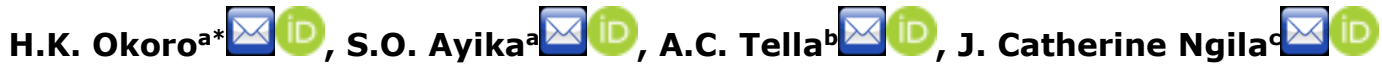 \\ a Environmental-Analytical \& Material Research Group, Department of Industrial Chemistry, Faculty of Physical \\ Sciences, P.M.B. 1515, University of Ilorin, Ilorin, Nigeria. \\ b Inorganic Chemistry and Synthesis Research Laboratory, Department of Chemistry, Faculty of Physical \\ Sciences, P.M.B. 1515, University of Ilorin, Ilorin, Nigeria. \\ C Analytical-Environmental and Membrane Nanotechnology Research Group, Department of Applied \\ Chemistry, University of Johannesburg, P.O. Box 17011, Doornfontein 2028, Johannesburg, Republic of \\ South Africa.
}

Abstract: The remediation of cadmium and lead ions from their respective aqueous solutions was carried out with the use of metal-organic frameworks (MOFs) developed from copper and zinc with benzene-1,4dicarboxylic acid (BDC). The experimental adsorption process was done in batches to determine the equilibrium characteristics, thermodynamics and kinetics of the sorption processes. The result was then tested using Langmuir, Freundlich, and Temkin isotherm equations with Langmuir being the best fitted isotherm, while the kinetics isotherm used were pseudo first order and pseudo second order. The result obtained shows that the MOFs are great potential adsorbent for the studied metals.

Keywords: Metal-Organic Frameworks, Lead, Cadmium, Remediation, Benzene-1,4-dicarboxylic acid (BDC)

Submitted: August 17, 2018. Accepted: March 30, 2019.

Cite this: Okoro $\mathrm{H}$, Ayika S, Tella A, Ngila J. METAL-ORGANIC FRAMEWORKS (MOFs) DERIVED FROM CARBOXYLATE LIGAND AS POTENTIAL MATERIALS FOR REMEDIATION OF Cd(II) AND Pb(II) FROM AQUEOUS SOLUTION. JOTCSA. 2019;6:165-76.

DOI: https://dx.doi.org/10.18596/jotcsa.454010.
*Corresponding
author.
E-mail:
okoroowo@yahoo.com;
hkoadeola@gmail.com;

Okoro.hk@unilorin.edu.ng.

\section{INTRODUCTION}

The contamination of both terrestrial systems and water bodies by toxic materials like heavy metals is a well known problem due to their hazardous and dangerous potentials when ingested into the system of human body (1-3). It is an indisputable fact that this pollution is largely due to the high level of urbanization and technological advancement $(4,5)$ and others may include population density, industrialization, and mechanization that makes available the necessities and needs of the increasing population (6-9). They are generally carried into food web leaches from dump sites, contaminated soil to plants and water bodies. The toxicity level of the metals increases as they are moving higher on the scale of the food chain by a process called bio-magnification. (1012). Metal-organic frameworks (MOFs) are presently undergoing an exponential number of researches and applications, as they are a unique type of porous materials (13-15). These are metal ions, which form covalent bonds with ligands to give crystal-like solids $(16,17)$. The presence of the ligands allows the structures to have spaces in 
between them giving rise to a large surface area (18-20).

\section{MATERIAL AND METHOD}

\section{Synthesis of Metal Organic Frameworks}

The copper- benzene 1, 4-dicarboxylic acid and zinc- benzene 1, 4-dicarboxylic acid metal-organic frameworks were synthesized using the method described by Tella et al. 2016 (21).

\section{Experimental procedure}

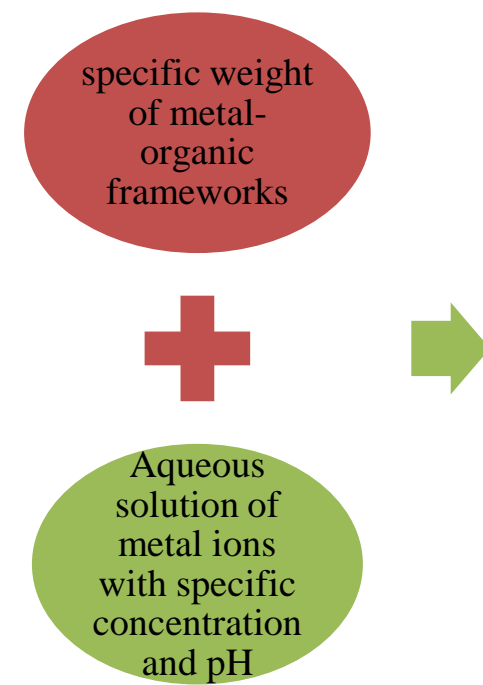

The MOFs were activated by heating at $120^{\circ} \mathrm{C}$ for 20 mins; it was then introduced into the conical flask containing the heavy metal solution and into a shaker. The adsorptive power of the MOFs was evaluated under various condition such as $\mathrm{pH}$, initial concentration of heavy metals, temperature, and adsorbent doses through various adsorption isotherm studies. The optimum removal condition for each metal was identified. The metal ions that were determined include cadmium and lead (22).

The scheme below shows the stepwise procedure for the batch adsorption process.

Scheme 1: The schematic representation of the adsorption process.

\section{Effect of Contact Time}

A weight of $0.025 \mathrm{~g}$ of the MOF was measured and added to $25 \mathrm{~mL}$ of the metal solution with a known initial concentration. The mixture was then placed into a shaker at a speed of $265 \mathrm{rpm}$ for 10, 20, 40, $60,80,100,150$ minutes, respectively. The mixture was then filtered and the concentration of the metal ion in the filtrate was determined (23).

\section{Effect of Adsorbent Dosage}

Various weights ranging from $0.01,0.03,0.05$, $0.07,0.09$ grams of the MOF was measured and added separately to $25 \mathrm{~mL}$ of a known concentration of the metal ion solution. The mixture was then placed into the shaker at a speed of 265 rpm for 60 minutes. The solution was then filtered and the concentration of the metal ion in the filtrate was determined (23).

\section{Effect of Initial Concentration of Metal Ion}

A weight of $0.025 \mathrm{~g}$ of the MOF was measured and added separately with $25 \mathrm{~mL}$ of the metal ion solution of varying concentration of the metal ion. The mixture was then placed into the shaker at a speed of $265 \mathrm{rpm}$ for $60 \mathrm{~min}$. The mixture was then filtered and the concentration of the metal ion was determined in the filtrate (22).

\section{Effect of Temperature}

A weight of $0.025 \mathrm{~g}$ of the MOF was weighed and introduced into a $25 \mathrm{~mL}$ solution of the metal ion. The mixture was then placed into a shaker at a speed of $265 \mathrm{rpm}$ for 60 minutes at different temperature ranges of $20,30,40,50,60^{\circ} \mathrm{C}$. The mixture was then filtered and the concentration of the metal ion was determined in the filtrate (22).

\section{Effect of pH}

A weight of $0.025 \mathrm{~g}$ of the MOF was weighed and added into $25 \mathrm{~mL}$ solution of the metal ion. The $\mathrm{pH}$ of the metal ion solution was varied using $0.01 \mathrm{M}$ $\mathrm{HCl}$ and $0.01 \mathrm{M} \mathrm{NaOH}$ within the range of 3, 5, 7, 9,11 and the mixture was then placed into the shaker at a speed of $265 \mathrm{rpm}$ for 60 minutes. The mixture was then filtered and the concentration of the metal ion was determined in the filtrate (23).

\section{RESULT AND DISCUSSION}

\section{Mechanism of Adsorption}

The mechanism of adsorption can be described as the relationship between the adsorbate and the adsorbent. 
Okoro HK et al. JOTCSA. 2019; 6(2): 165-176.

MOFs

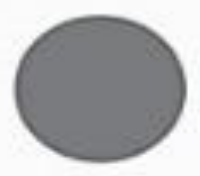

Adsorbent
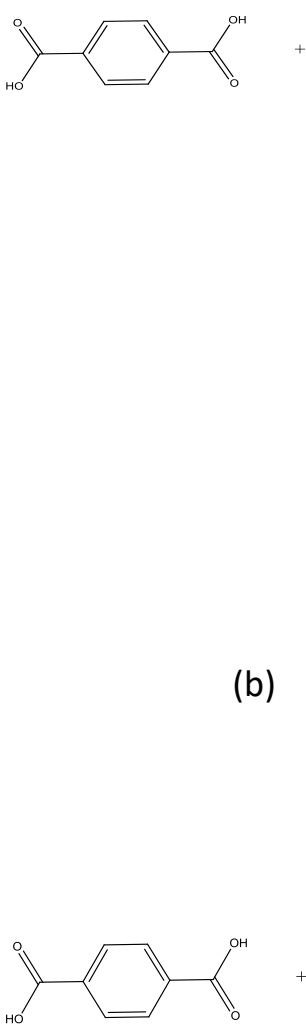

(b)
Metal ions

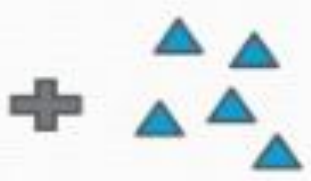

Adsorbate

Metal ions on the MOFs

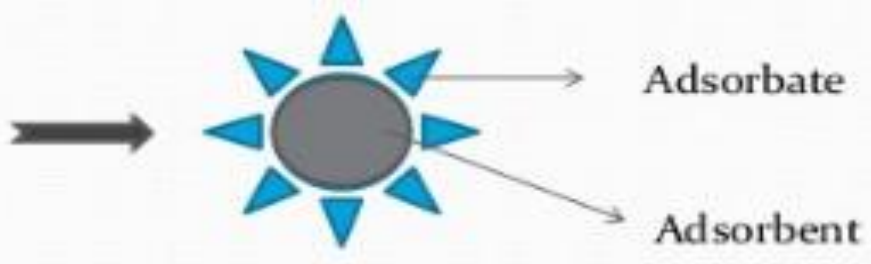

(a)
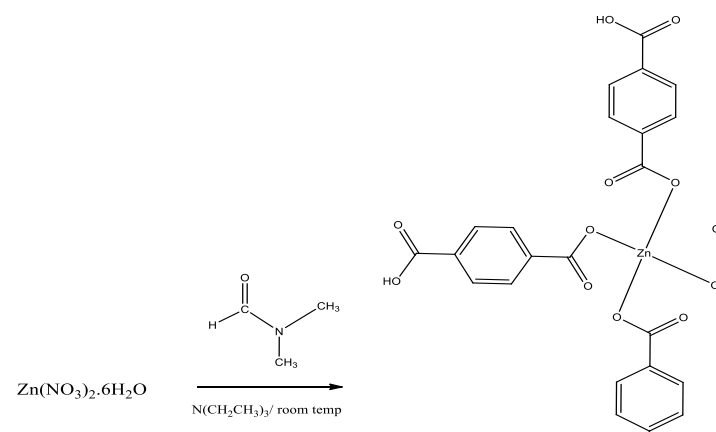

$\mathrm{Zn}\left(\mathrm{NO}_{3}\right)_{2} \cdot 6 \mathrm{H}_{2} \mathrm{O}$

$\mathrm{N}\left(\mathrm{CH}_{2} \mathrm{CH}_{3}\right)_{3}$ room tem

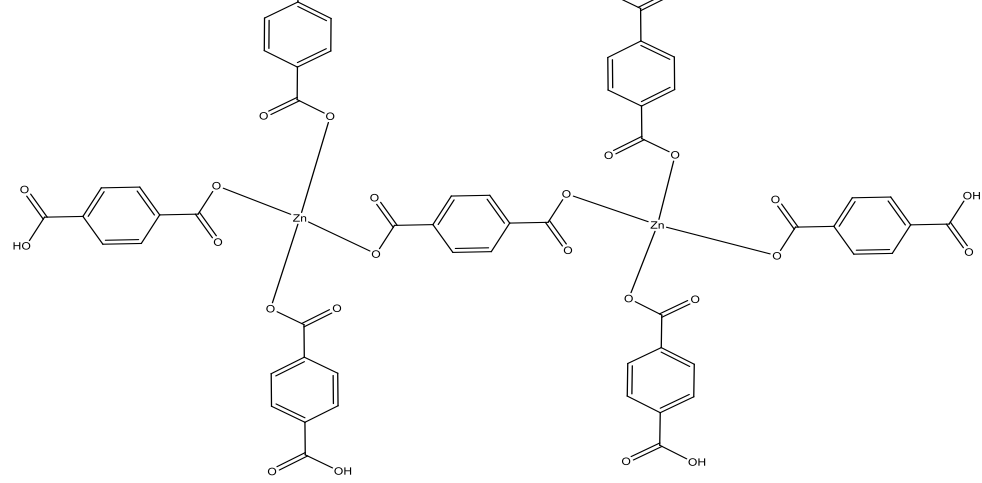

CuOAC
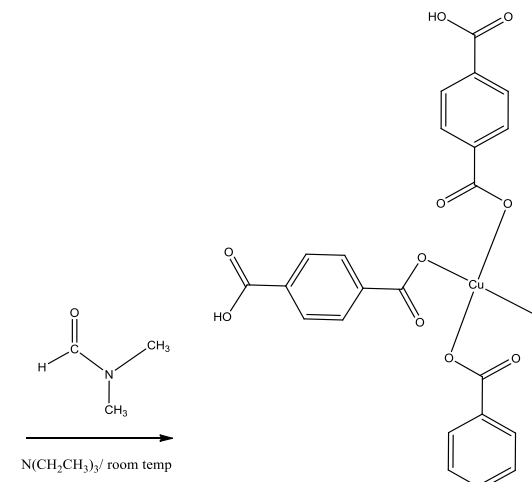<smiles>O=C(O)C1CC2C=CC1C2</smiles>
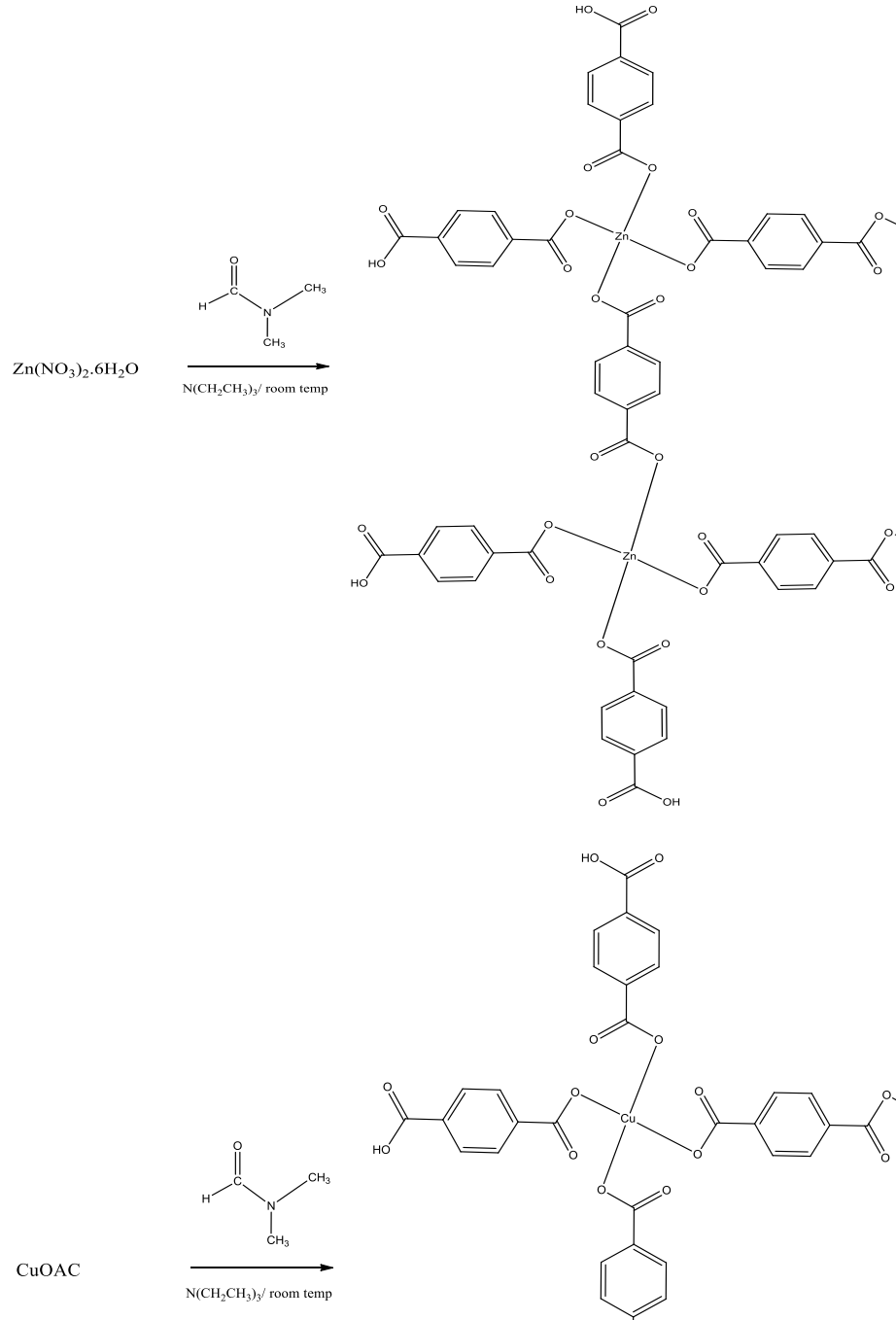<smiles>CC(C)c1ccc(C(C)Cl)cc1</smiles>
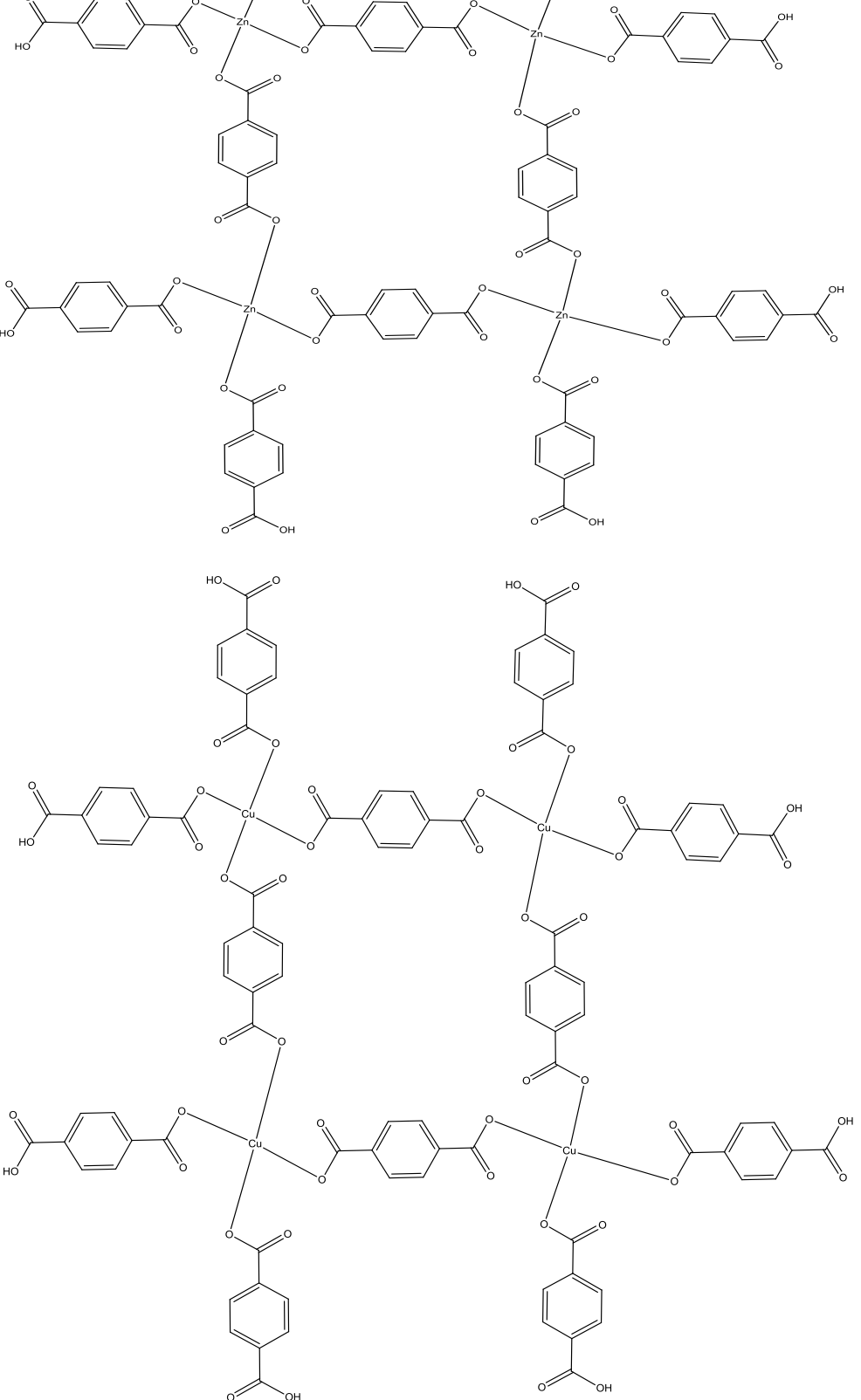

Scheme 2: Reaction scheme for the formation of (a) zinc and (b) copper metal organic frameworks. 


\section{Effect of Initial Metal Concentration}

The adsorption performance of the $\mathrm{Cu}-\mathrm{BDC}$ and $\mathrm{Zn}$ BDC MOFs was determined as related to the concentration of the metal ions initially. These concentrations range from $40 \mathrm{ppm}$ to $200 \mathrm{ppm}$ for all the metals studied at a pH of 7, temperature of $30{ }^{\circ} \mathrm{C}, 0.025 \mathrm{~g}$ of adsorbent and 60 minutes of contact time. The adsorption of the metals increase with increase in the concentration of the metal was obtained initially then a gradual decrease in the adsorptivity of the metals with further increase in the concentration of the metals. Comparatively, the amount of metal adsorbed by the Cu-BDC MOFs is in the order $\mathrm{Cd}<\mathrm{Pb}$, while for the Zn-BDC MOFs its adsorptivity is in the order $\mathrm{Cd}<\mathrm{Pb}$. Comparing the two MOFs the adsorptive strength is in the order Cd-ZnBDC $<$ Cd-CuBDC $<$ Pb-ZnBDC $<$ Pb-CuBDC.

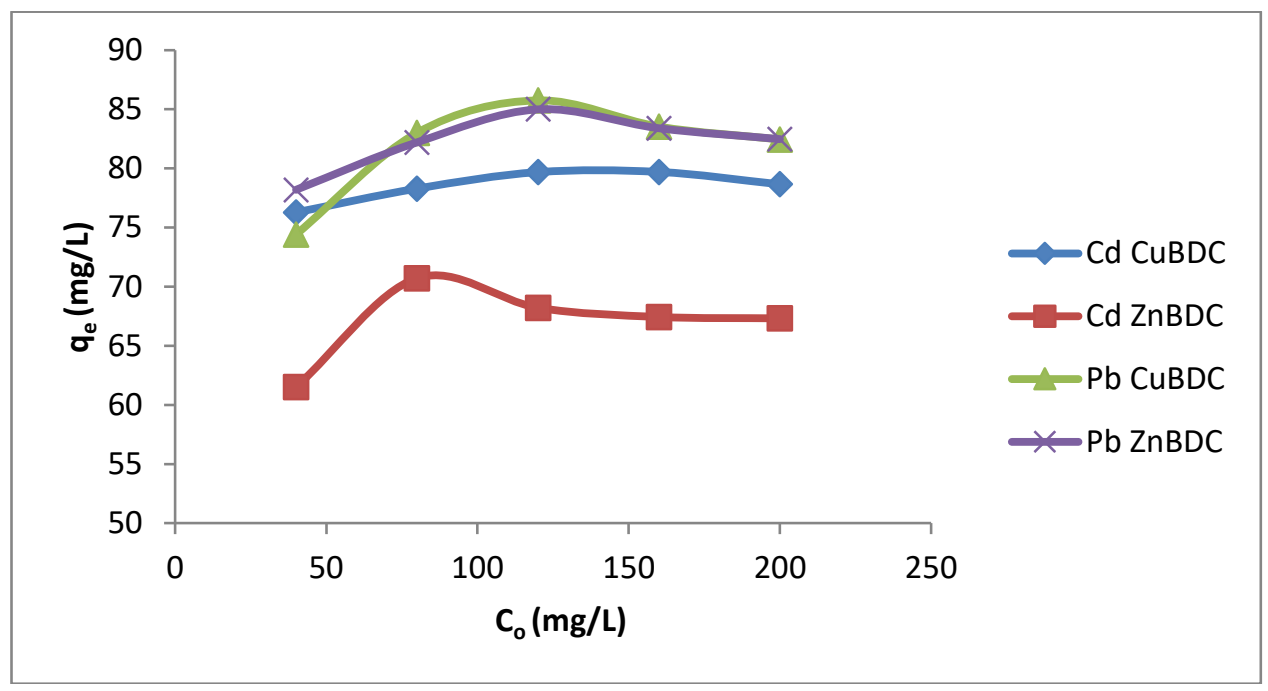

Figure 1: Effect of initial metal concentration for $\mathrm{Cu}$ and $\mathrm{Pb}$ metal with CuBDC and ZnBDC MOFs.

As shown in Figure 1 above, the quantity of cadmium and lead metal ions adsorbed by both CuBDC and ZnBDC increased with increase in concentration but a gradual reduction in the quantity of metal ions removed was noted with further increase in the concentration of the metal. The optimum quantity of cadmium metal adsorbed was $157.316 \mathrm{mg} / \mathrm{g}$ and $134.643 \mathrm{mg} / \mathrm{g}$ likewise $79.7 \%$ and $70.7 \%$ for the CuBDC and ZnBDC MOFs respectively while the optimum quantity of lead metal ion adsorbed was $164.906 \mathrm{mg} / \mathrm{g}$ and 164.960 $\mathrm{mg} / \mathrm{g}$ likewise $85.7 \%$ and $84.9 \%$ for the CuBDC and ZnBDC MOFs respectively. A similar result was observed by Shooto et al. (24).

\section{Effect of Adsorbent Dose}

The result of the effect of adsorbent dosage on the removal of $\mathrm{Cd}$ and $\mathrm{Pb}$ metal ions from aqueous solution. The results show the relationship between the quantity of the adsorbent and the amount of metal adsorbed.

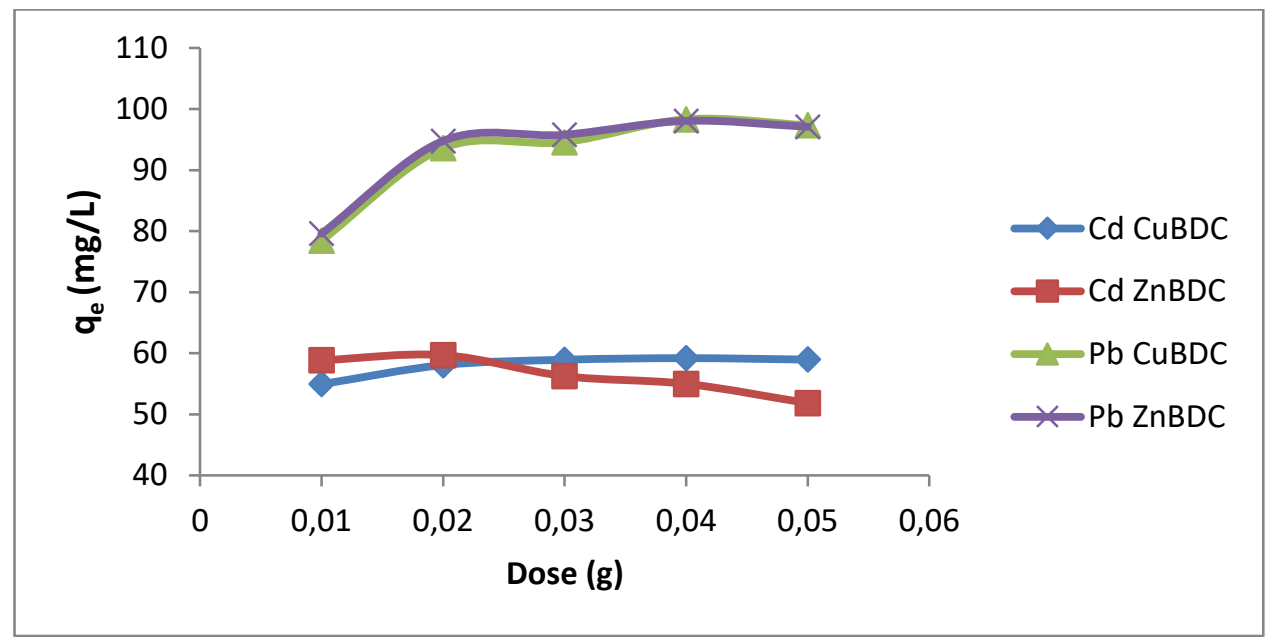

Figure 2: Effect of adsorbent dose for $\mathrm{Cd}$ and $\mathrm{Pb}$ metal ions with CuBDC and ZnBDC MOFs. 
The Figure 2 above shows the behavior of the dose of the adsorbent on the quantity of the cadmium and lead metal adsorbed by the $\mathrm{Cu}-\mathrm{BDC}$ and $\mathrm{Zn}$ $\mathrm{BDC}$. The $\mathrm{Cu}-\mathrm{BDC}$ performed the best with $0.04 \mathrm{~g}$ of the adsorbent while the $\mathrm{Zn}-\mathrm{BDC}$ was $0.02 \mathrm{~g}$ of the MOFs for cadmium metal, while the Cu-BDC performed the best with $0.04 \mathrm{~g}$ of the adsorbent while the $\mathrm{Zn}-\mathrm{BDC}$ was $0.04 \mathrm{~g}$ of the MOFs for the lead metal ions.

\section{Effect of Contact Time}

The significance of contact duration arises from the fact that there is need for the identification of the rapidness at which the metal ions bind to and removed from the surface of the MOFs. Thus the optimal time for the adsorptive procedure of the heavy metals were obtained.

The effect of contact time for $\mathrm{Cd}$ and $\mathrm{Pb}$ ions was studied at $\mathrm{pH} 7$, temperature of $30{ }^{\circ} \mathrm{C}, 0.025 \mathrm{~g}$ of the adsorbent and a concentration of $100 \mathrm{ppm}$. The contact time was varied in the range $10,20,40$, $60,80,100,120$ and 150 minutes.

An initial increment in the amount of the ions adsorbed was noticed with increase in time until equilibrium was reached, a decrease was then obtained with further increase of the contact time. The Figure 3 below shows the effect of the contact time on each of the metals and the MOFs.

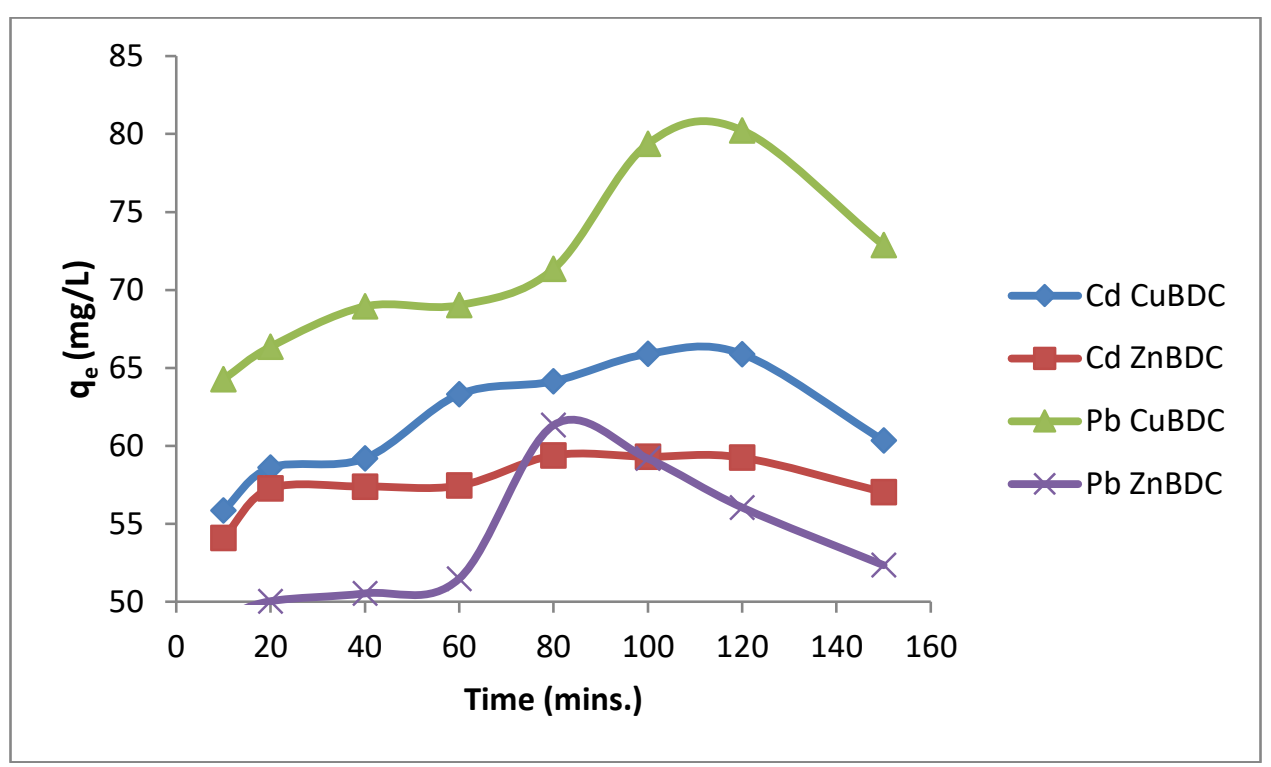

Figure 3: Effect of contact time for $\mathrm{Cd}$ and $\mathrm{Pb}$ metal ions with CuBDC and ZnBDC MOFs.

The Figure 3 above shows that the optimum contact time was obtained for cadmium and lead metal ions by the MOFs, the optimum time obtained for cadmium ion with the CUBDC is 100 minutes while that of the ZnBDC was found to be 80 minutes as well, on the other hand the optimum contact time obtained for lead ion by the MOFs, the optimum time obtained for the CuBDC is 120 minutes while that of the ZnBDC was found to be 80 minutes. Abbas et al. (23) reported a similar result.

\section{Effect of Temperature}

The exothermic or endothermic nature of the process was determined, the adsorption capabilities of the MOFs was studied over a range of temperature. The temperature range considered for this study is 20,30, 40, 50 and $60{ }^{\circ} \mathrm{C}$ respectively at a pH of $7,0.025 \mathrm{~g}$ of adsorbent, 100 $\mathrm{ppm}$ metal ion concentration and 60 minutes of contact time. A steady increase was observed until an optimum amount was obtained and further increase in the temperature leads to a decrease metal ions adsorbed. This can be attributed to the weakening effect that high temperature may have on the attractive forces between the adsorbent and adsorbate. At high temperature, there is an increased tendency of the metal ion escaping from the surface of the adsorbent to the solution due to the increase in kinetic energy that is supplied by the rise in temperature. 


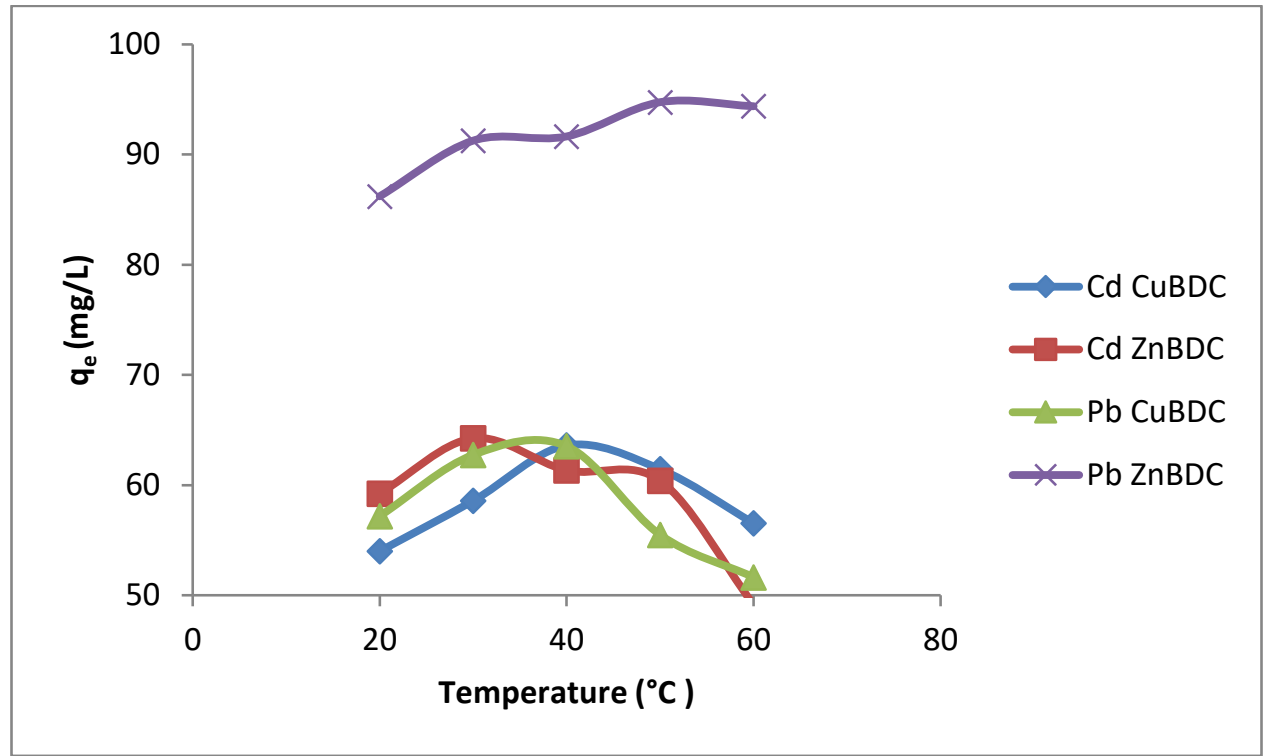

Figure 4: Effect of temperature for $\mathrm{Cd}$ and $\mathrm{Pb}$ metal with $\mathrm{CuBDC}$ and $\mathrm{ZnBDC}$ MOFs.

The Figure 4 above shows the optimum adsorption temperature obtained for cadmium and lead metal ions by the MOFs, the optimum temperature obtained for cadmium metal ion with the CuBDC is $40{ }^{\circ} \mathrm{C}$ while that of the ZnBDC was found to be 30 ${ }^{\circ} \mathrm{C}$. The optimum temperature obtained for lead metal ion with the CuBDC is $40^{\circ} \mathrm{C}$ while that of the $\mathrm{ZnBDC}$ was found to be $50{ }^{\circ} \mathrm{C}$. Barka et al. (25) reported a similar result.

\section{Effect of pH}

$\mathrm{pH}$ is one of the major factors influencing the adsorptive capabilities of metal ions. The adsorption characteristics of the $\mathrm{Cd}$ and $\mathrm{Pb}$ ions were studied at various $\mathrm{pH}$ values ranging from 3 , $5,7,9$ and 11 at a temperature of $30^{\circ} \mathrm{C}, 0.025 \mathrm{~g}$ of adsorbent, 100 ppm of metal ion concentration, and 60 minutes of contact time. The result shows that the optimum $\mathrm{pH}$ for adsorption of $\mathrm{Cd}$ and $\mathrm{Pb}$ ions by the CuBDC MOFs is $\mathrm{pH} 9$ while for the ZnBDC MOFs the values obtained shows that the optimum adsorption for $\mathrm{Cd}$ is $\mathrm{pH}$ of 5 and $\mathrm{Pb}$ is $\mathrm{pH}$ of 9 .

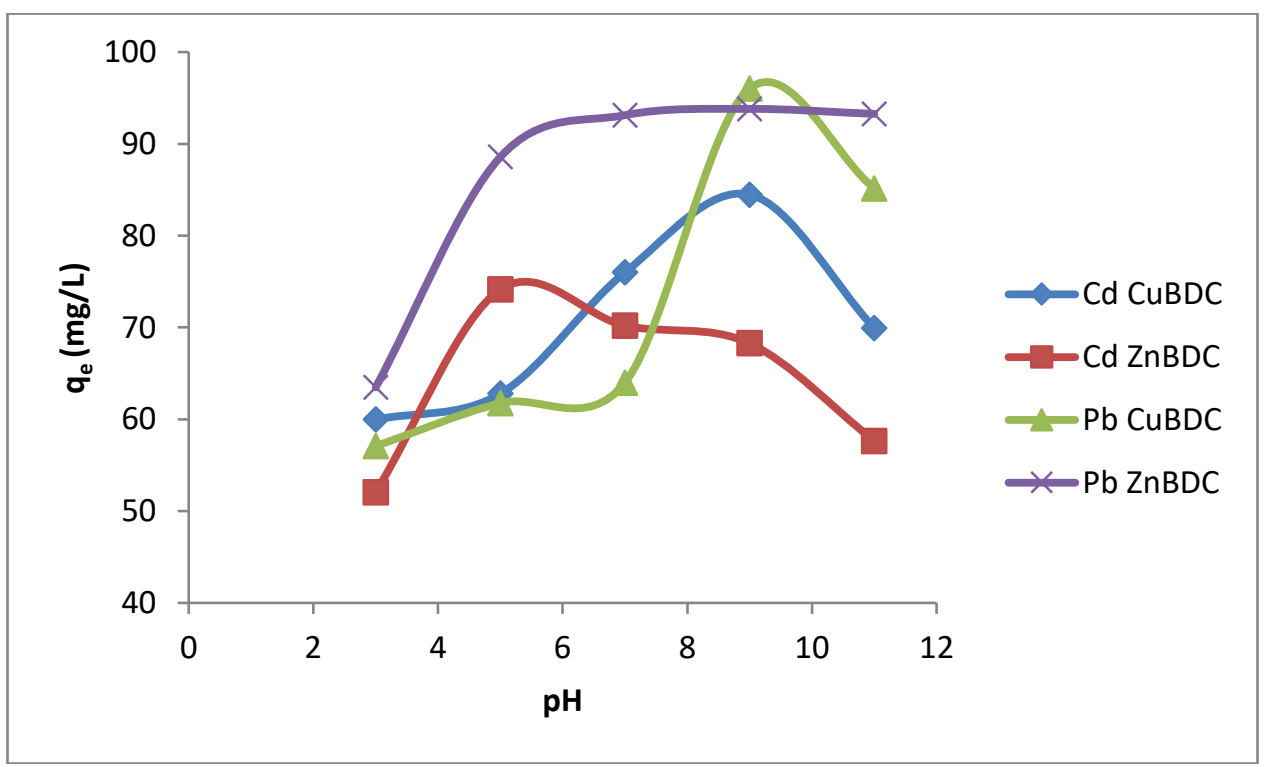

Figure 5: Effect of $\mathrm{pH}$ for $\mathrm{Cd}$ and $\mathrm{Pb}$ metal ions with $\mathrm{CuBDC}$ and $\mathrm{ZnBDC}$ MOFs.

The Figure 5 above shows the optimum pH obtained for copper and lead metal by the MOFs, the optimum $\mathrm{pH}$ values obtained for cadmium metal with the CuBDC is $\mathrm{pH} 9$ while that of the $\mathrm{ZnBDC}$ was found to be $\mathrm{pH} 5$, the optimum $\mathrm{pH}$ values obtained for lead metal by the MOFs, the optimum $\mathrm{pH}$ 
obtained for the CuBDC is $\mathrm{pH} 9$ while that of the $\mathrm{ZnBDC}$ was found to be $\mathrm{pH} 9$ as well. Ajmal et al. (26) reported a similar result.

\section{Adsorption Isotherm}

Adsorption isotherm is an important description on how solutes interact with adsorbents. A number of models have been developed over the years for evaluating the equilibrium for adsorption of substances from their solution. The adsorption data obtained from this work were tested with Langmuir, Freundlich, and Temkin adsorption isotherms.

\section{Langmuir Adsorption Isotherm}

The data obtained from the adsorption process for cadmium and lead ions with $\mathrm{Cu}-\mathrm{BDC}$ and $\mathrm{Zn}-\mathrm{BDC}$ MOFs over the concentration range of $40-200 \mathrm{ppm}$ at $30^{\circ} \mathrm{C}$ has been correlated with the Langmuir isotherm. A graph of $\mathrm{Ce} / \mathrm{qe}$ versus $\mathrm{Ce}$ was plotted and a linear plot was obtained. The data obtained and parameters tested are reported in the Table 1 below.

Table 1: The Langmuir isotherm parameters and the value obtained for each metal and MOFs.

\begin{tabular}{lllll}
\hline Parameter / Metal-MOFs & Cadmium Cu-BDC & Cadmium Zn-BDC & Lead Cu-BDC & Lead Zn-BDC \\
\hline $\mathrm{R}^{2}$ & 0.9996 & 0.9979 & 0.9961 & 0.9988 \\
$\mathrm{q}_{\max }$ & 79.365 & 68.027 & 84.75 & 84.03 \\
$\mathrm{~K}_{\mathrm{L}}$ & 4.200 & 2.774 & 1.84 & 4.10 \\
$\mathrm{R}_{\mathrm{L}}$ & 0.0059 & 0.0089 & 0.013 & 0.0061 \\
\hline
\end{tabular}

Where: $\mathrm{R}^{2}$ is the correlation coefficient, $\mathrm{q}_{\max }$ is the maximum amount of adsorbate adsorbed per unit mass of adsorbent, $\mathrm{K}_{\mathrm{L}}$ is Langmuir isotherm constant, $R_{L}$ is the separation factor.

The regression coefficient values $\left(R^{2}\right)$ show the applicability of the isotherm to the adsorption process. The values obtained shows that the
Langmuir isotherm is suitable for the adsorbents studied. A similar result was obtained by Demirbas et al. (27).

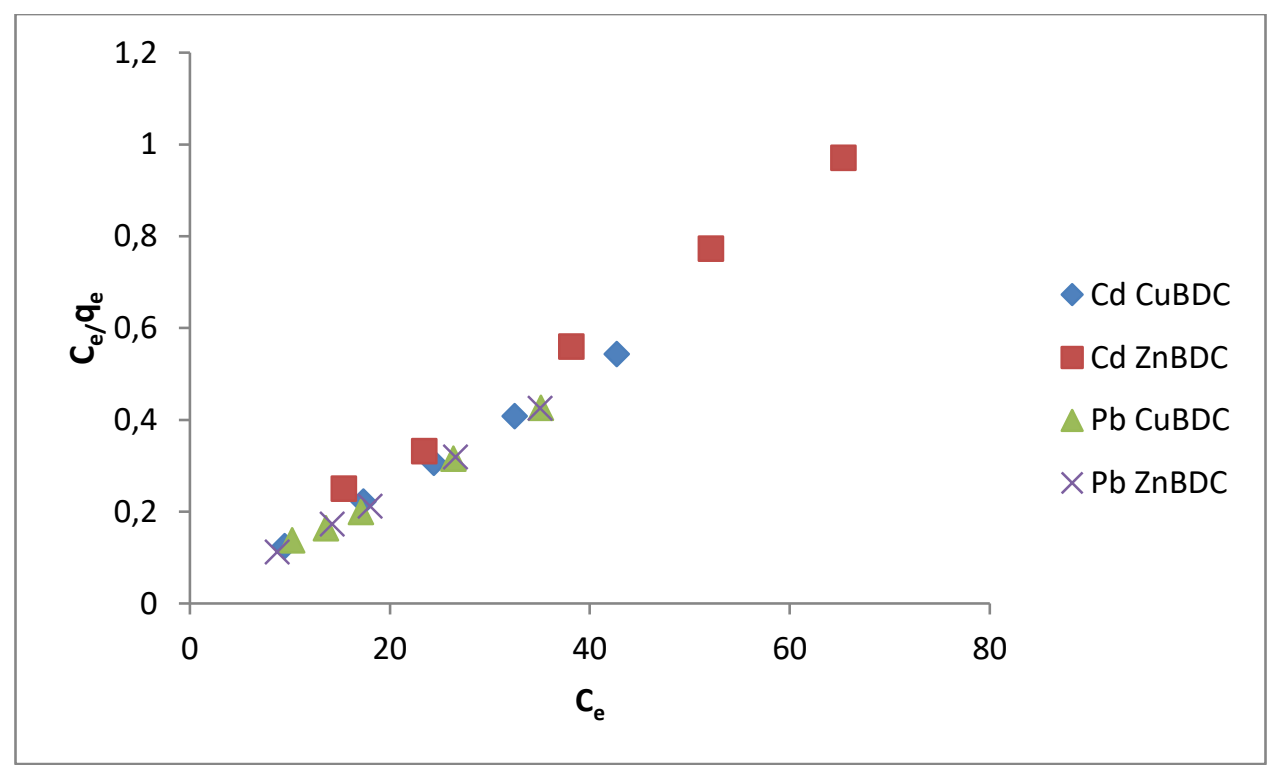

Figure 6: Langmuir adsorption isotherm plot for cadmium and lead metal ions with CuBDC and ZnBDC MOFs.

\section{Freundlich Adsorption Isotherm}

The data obtained from the adsorption process for cadmium and lead ions with $\mathrm{Cu}-\mathrm{BDC}$ and $\mathrm{Zn}-\mathrm{BDC}$ MOFs over the concentration range of $40-200 \mathrm{ppm}$ at $30{ }^{\circ} \mathrm{C}$ has been correlated with the Freundlich isotherm. A graph of log qe versus log Ce was plotted and a linear plot was obtained. The data obtained and parameters tested are reported in the Table 2 below. 
Table 2: The Freundlich isotherm parameters and the value obtained for each metal and MOFs.

\begin{tabular}{lllll}
\hline Parameter/ Metal-MOFs & Cadmium Cu-BDC & Cadmium Zn-BDC & Lead Cu-BDC & Lead Zn-BDC \\
$\mathrm{R}^{2}$ & 0.9941 & 0.9578 & 0.8824 & 0.9607 \\
$\mathrm{~K}_{\mathrm{F}}$ & 2.595 & 1.395 & 17.58 & 25.08 \\
$\mathrm{n}$ & 0.9003 & 0.903 & 0.779 & 0.837 \\
\hline
\end{tabular}

Where: $\mathrm{R}^{2}$ is the correlation coefficient, $\mathrm{K}_{\mathrm{F}}$ is the Freundlich isotherm constant, $\mathrm{n}$ is the adsorption intensity. The regression coefficient values $\left(R^{2}\right)$ show the applicability of the isotherm to the adsorption process. The values obtained shows that the Freundlich isotherm is suitable for the adsorption process studied.

\section{Temkin Adsorption Isotherm}

The data obtained from the adsorption process for cadmium and lead ions with $\mathrm{Cu}-\mathrm{BDC}$ and $\mathrm{Zn}-\mathrm{BDC}$ MOFs over the concentration range of $40-200 \mathrm{ppm}$ at $30{ }^{\circ} \mathrm{C}$ have been correlated with the Temkin isotherm. A graph of qe versus In Ce was plotted and a linear plot was obtained. The data obtained and parameters tested are reported in the Table 3 below.

Table 3: Temkin isotherm parameters and the value obtained for each metal and MOFs.

\begin{tabular}{lllll}
\hline Parameters/ Metal-MOFs & Cadmium Cu-BDC & Cadmium Zn-BDC & Lead Cu-BDC & Lead Zn-BDC \\
$\mathrm{R}^{2}$ & 0.9716 & 0.9839 & 0.9821 & 0.9886 \\
$\mathrm{~B}_{\mathrm{T}}$ & 85.021 & 72.311 & 76.612 & 71.303 \\
$\mathrm{~K}_{\mathrm{T}}$ & 0.136 & 0.0897 & 0.112 & 0.097 \\
\hline
\end{tabular}

Where: $\mathrm{R}^{2}$ is the correlation coefficient, $\mathrm{B}_{\mathrm{T}}$ is the Temkin isotherm constant, $\mathrm{K}_{\mathrm{T}}$ is the Temkin isotherm equilibrium. The regression coefficient values $\left(R^{2}\right)$ show the applicability of the isotherm to the adsorption process. The values obtained show that the Temkin isotherm is suitable for the adsorption process studied.
The correlation of the adsorption data ( $R^{2}$ values) obtained from the adsorption process of cadmium and lead by Cu-BDC and Zn-BDC MOFs with the Langmuir, Freundlich and Temkin adsorption isotherms is shown in the Table 4 below.

Table 4: Comparism of the $\mathrm{R}^{2}$ values obtained for the adsorption process.

\begin{tabular}{lllll}
\hline Isotherms/ Metal-MOFs & Cadmium Cu-BDC & Cadmium Zn-BDC & Lead Cu-BDC & Lead Zn-BDC \\
Langmuir & 0.9996 & 0.9979 & 0.9961 & 0.9988 \\
Freundlich & 0.9941 & 0.9578 & 0.8824 & 0.9607 \\
Temkin & 0.9716 & 0.9839 & 0.9821 & 0.9886 \\
\hline
\end{tabular}

From the Table 4 above, the adsorption data obtained from this study fitted best into the Langmuir adsorption isotherm suggesting that the adsorption process is more of monolayer sorption than heterogeneous energy distribution.

\section{Adsorption Kinetic Models}

To understand the adsorption kinetics, the adsorption process was performed at various durations of time and the amount of cadmium and lead ions adsorbed by the $\mathrm{Cu}-\mathrm{BDC}$ and $\mathrm{Zn}-\mathrm{BDC}$ MOFs respectively. The data obtained was subjected to the pseudo first order and pseudo second order kinetic models.

\section{Pseudo First Order Kinetic Model}

The adsorption data were tested with the pseudo first order kinetic model which is represented by the equation: $\log [q e-q t]=\log [q e]-\left[k_{1} / 2.303\right]$ t. $A$ plot log (qe-qt) against time was done and the values of the first order kinetic constant $\left(k_{1}\right)$ was determined by

$$
\mathrm{K}_{1}=- \text { slope } / 2.303 .
$$

Table 5: The pseudo first order kinetic model parameters and the value obtained for each metal and MOFs.

\begin{tabular}{lllll}
\hline Parameter/ Metal-MOFs & Cadmium Cu-BDC & Cadmium Zn-BDC & Lead Cu-BDC & Lead Zn-BDC \\
\hline $\mathrm{R}^{2}$ & 0.2751 & 0.2860 & 0.4579 & 0.1430 \\
$\mathrm{q}_{\mathrm{e}}$ (exp) & 65.898 & 59.386 & 80.238 & 61.321 \\
$\mathrm{q}_{\mathrm{e}}$ (cal) & 10.141 & 3.236 & 17.758 & 9.894 \\
$\mathrm{~K}_{1}$ & 0.00439 & 0.00295 & 0.00243 & 0.00134 \\
\hline
\end{tabular}

Where: $\mathrm{R}^{2}$ is the correlation coefficient, $\mathrm{q}_{\mathrm{e}}(\exp )$ is the experimentally measured adsorbate concentration at equilibrium, $\mathrm{q}_{\mathrm{e}}(\mathrm{cal})$ is the calculated adsorbate concentration at equilibrium,
$\mathrm{K}_{1}$ is the rate constant of pseudo first order adsorption. The regression coefficient values $\left(R^{2}\right)$ show that applicability of the kinetic model to the adsorption process. The values obtained shows that 
the pseudo first order kinetic model is not suitable for the adsorption process studied.

\section{Pseudo Second Order Kinetic Model}

The adsorption data were tested with the pseudo second order kinetic model which is represented by the equation: $t / q t=1 / k_{2} q_{e}^{2}+[1 / q e] t$. A plot t/qt against time was carried out and the values of the second order kinetic constant $\left(k_{1}\right)$ was determined by

$$
\mathrm{K}_{2}=1 / \mathrm{qe}^{2 *} \text { intercept }
$$

Table 6: The pseudo second order kinetic model parameters and the value obtained for each metal and MOFs.

\begin{tabular}{lllll}
\hline Parameter/ Metal-MOFs & Cadmium Cu-BDC & Cadmium Zn-BDC & Lead Cu-BDC & Lead Zn-BDC \\
\hline $\mathrm{R}^{2}$ & 0.9939 & 0.9987 & 0.9921 & 0.9873 \\
$\mathrm{q}_{\mathrm{e}}(\exp )$ & 65.898 & 59.386 & 80.238 & 61.321 \\
$\mathrm{q}_{\mathrm{e}}$ (cal) & 63.291 & 58.140 & 77.519 & 55.249 \\
$\mathrm{~K}_{2}$ & 0.0294 & 0.269 & 0.00358 & 0.0287 \\
\hline
\end{tabular}

Where: $\mathrm{R}^{2}$ is the correlation coefficient, $\mathrm{q}_{\mathrm{e}}(\exp )$ is the experimentally measured adsorbate concentration at equilibrium, $\mathrm{q}_{\mathrm{e}}(\mathrm{cal})$ is the calculated adsorbate concentration at equilibrium, $\mathrm{K}_{2}$ is the rate constant of pseudo second order adsorption. The regression coefficient values $\left(R^{2}\right)$ show that applicability of the kinetic model to the adsorption process. The values obtained shows that the pseudo second order kinetic model is suitable for the adsorption process studied.

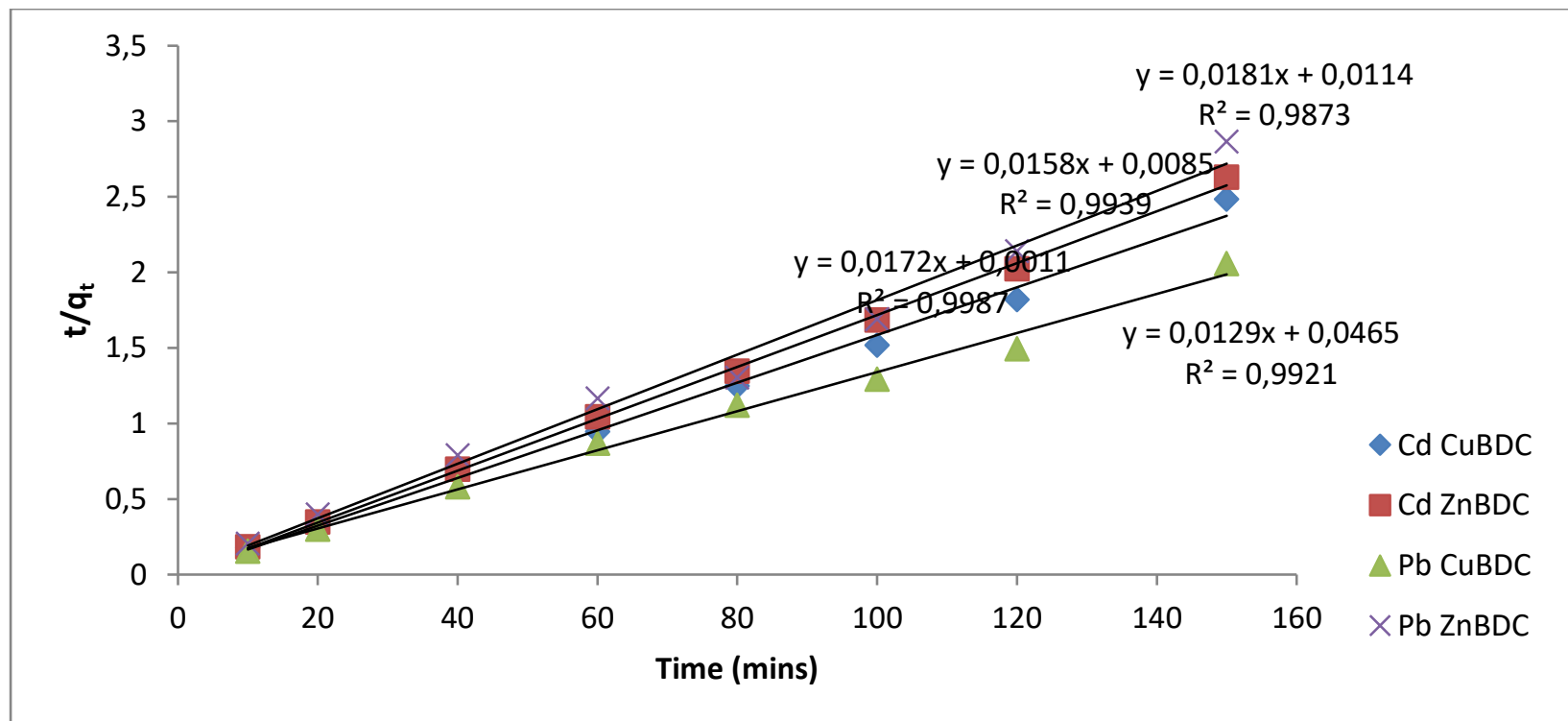

Figure 7: Pseudo second order kinetics model plot for cadmium and lead metal with CuBDC and ZnBDC MOFs.

The linearity of the second order kinetics is better when compared with the first order judging by the $R^{2}$ values. The $R^{2}$ of the plots of this study as shown on Table 6 above proves that the pseudo second order kinetics model is more effective in representing the kinetics data obtained from the study. This suggests that the kinetics of the adsorption of cadmium and lead onto CuBDC and
ZnBDC MOFs can be described using pseudo second order kinetics model and hence suggests that the adsorption process is more of physical process. The pseudo second order also gave a better correlation of the calculated values of the adsorption capacities qe (cal) with those obtained from the experimental process. A similar result was reported by Okoli and Ezuma 2014 (28) and Ezekiel and Abdullahi (29). 
Okoro HK et al. JOTCSA. 2019; 6(2): 165-176.

\section{Re-Usability Test}

Table 7: Re-usability capacity of the MOFs for each metal ion studied.

\begin{tabular}{lllll}
\hline $\begin{array}{l}\text { Parameter/ } \\
\text { Metal-MOFs }\end{array}$ & \multicolumn{1}{c}{ Cadmium Cu-BDC (\%) } & Cadmium Zn-BDC (\%) & Lead Cu-BDC (\%) & Lead Zn-BDC (\%) \\
\hline 1 & 60.242 & 59.995 & 58.865 & 49.341 \\
2 & 60.152 & 59.665 & 58.463 & 49.443 \\
3 & 59.987 & 58.352 & 57.382 & 48.388 \\
4 & 59.675 & 56.364 & 57.887 & 49.182 \\
5 & 58.142 & 55.876 & 57.284 & 48.382 \\
\hline
\end{tabular}

The table above shows the result of the re-usability test of the MOFs. This suggests that the MOFs have excellent recovery and re-usability capacity. A similar result was reported by Wu et al., 2012 (30).

\section{CONCLUSION}

Two known MOFs were successfully synthesized by means of solvent based reflux procedure. They were prepared from $\mathrm{Cu}(\mathrm{II}), \mathrm{Zn}(\mathrm{II})$ and benzene1,4-dicarboxylic acid. The adsorptive capabilities of the MOFs were carried out by using them for the adsorption of $\mathrm{Cd}$ and $\mathrm{Pb}$ metal ions from their respective solutions. The MOFs performed well when compared with others in the literature. The various adsorption physicochemical parameters were used to determine the optimal condition for the use of these MOFs in the removal of the metals in their solutions. The data were investigated by the Langmuir, Freundlich and Temkin adsorption isotherm which they fitted into well with regards to the correlation values $\left(R^{2}\right)$ obtained, with the best being the Langmuir isotherm in comparison with others. The adsorption kinetics follows the pseudo second order kinetics model with reference to the correlation data obtained. The MOFs show a great strength in the recovery and re-usability study. Conclusively, the synthesized MOFs have proven to be potentially great heavy metal adsorbents from their aqueous solutions.

\section{ACKNOWLEDGEMENT}

The authors Dr HK Okoro and Prof JC Ngila thanks UJ Global Excellence and Stature Scholarship for running cost paid by Water Research Commission WRC Project No. K5/2365. A.C. Tella is grateful to the Royal Society of Chemistry for the award of 2013 research fund. The authors also thank University of Ilorin, Ilorin, Nigeria and University of Johannesburg, South Africa, for making available the library database and Laboratory facilities.

\section{REFERENCES}

1. Okoro HK, Ige JO, Iyiola OA, Ngila JC. Fractionation profile, mobility patterns and correlations of heavy metals in estuary sediments from olonkoro river, in tede catchment of western region, Nigeria. Environmental nanotechnology, monitoring \& management. 2017;8:5362.
2. Gielar A, Helios-Rybicka E, Möller S, Einax JW. Multivariate analysis of sediment data from the upper and middle Odra River (Poland). Applied Geochemistry. 2012;27(8):1540-5

3. Mobasherpour I, Salahi E, Asjodi A. Research on the batch and fixed-bed column performance of red mud adsorbents for lead removal. soil and water. 2014;4:5.

4. Okoro HK, Adeyinka A, Jondiko OE, Ximba BJ. Physicochemical analysis of selected groundwater samples of Ilorin town in Kwara State, Nigeria. Scientific Research and Essays. 2012;7(23):2063-9.

5. Aguayo-Villarreal IA, Bonilla-Petriciolet A, HernándezMontoya V, Montes-Morán MA, Reynel-Avila HE. Batch and column studies of $\mathrm{Zn} 2+$ removal from aqueous solution using chicken feathers as sorbents. Chemical Engineering Journal. 2011;167(1):67-76.

6. Venkatesham V, Madhu G, Satyanarayana S, Preetham $\mathrm{H}$. Adsorption of lead on gel combustion derived nano ZnO. Procedia Engineering. 2013;51:308-13.

7. Yang $\mathrm{H}$, Rose $\mathrm{N}$. Distribution of $\mathrm{Hg}$ inthe lake sediments across the UK. Science of the Total Environment. 2003;304:391-404.

8. Okoro HK, Fatoki OS, Adekola FA, Ximba BJ, Snyman RG. Geochemical assessment of sediment in Cape Town harbour, South Africa. Bulletin of the Chemical Society of Ethiopia. 2014;28(1):17-28.

9. Okoro H, Alao S, Adebayo G, Basheer K. Evaluation of heavy and trace metals in fingernails of young school children and adults in Ilorin, Kwara State, Nigeria. Journal of Applied Sciences and Environmental Management. 2015;19(2):319-24.

10. Aman T, Kazi AA, Sabri MU, Bano Q. Potato peels as solid waste for the removal of heavy metal copper (II) from waste water/industrial effluent. Colloids and Surfaces B: Biointerfaces. 2008;63(1):116-21.

11. Paknikar K, Pethkar A, Puranik P. Bioremediation of metalliferous wastes and products using inactivated microbial biomass. 2003;

12. Kuppler RJ, Timmons DJ, Fang Q-R, Li J-R, Makal TA, Young MD, et al. Potential applications of metal-organic 
frameworks. Coordination Chemistry Reviews. 2009 Dec;253(23-24):3042-66.

13. Li Z, Ma Z, van der Kuijp TJ, Yuan Z, Huang L. A review of soil heavy metal pollution from mines in China: Pollution and health risk assessment. Science of The Total Environment. 2014 Jan;468-469:843-53.

14. Sagar T, Shah P. Adsorptive Removal of Hazardous Waste Materials using Metal-Organic Frameworks. In 2014. p. 469-71.

15. Ruyra À, Yazdi A, Espín J, Carné-Sánchez A, Roher N, Lorenzo J, et al. Synthesis, Culture Medium Stability, and In Vitro and In Vivo Zebrafish Embryo Toxicity of MetalOrganic Framework Nanoparticles. Chemistry - A European Journal. 2015 ubat;21(6):2508-18.

16. Mahata P, Ramya KV, Natarajan S. Synthesis, structure and optical properties of rare-earth benzene carboxylates. Dalton Transactions. $2007 ;(36): 4017$.

17. Sajid M, Ilyas M, Basheer C, Tariq M, Daud M, Baig N, et al. Impact of nanoparticles on human and environment: review of toxicity factors, exposures, control strategies, and future prospects. Environmental Science and Pollution Research. 2015 Mar;22(6):4122-43.

18. Adediran G, Tella A, Mohammed $\mathrm{H}$. Adsorption of Pb, $\mathrm{Cd}, \mathrm{Zn}, \mathrm{Cu}$ and $\mathrm{Hg}$ ions on Formaldehyde and Pyridine Modified Bean Husks. Journal of Applied Sciences and Environmental Management [Internet]. 2010 Jun 1 [cited 2019 Apr 4];11(2). Available from: http://www.ajol.info/index.php/jasem/article/view/5501 9

19. Pally N. Synthesis and Structures of New ThreeDimensional Copper Metal-Organic Frameworks [Internet] [Master of Science Thesis]. [Kentucky, USA]: Western Kentucky University; 2013. Available from: http://digitalcommons.wku.edu/theses/1295

20. Ryder MR, Tan J-C. Nanoporous metal organic framework materials for smart applications. Materials Science and Technology. 2014 Nov;30(13):1598-612.

21. Tella AC, Owalude SO, Olatunji SJ, Adimula VO, Elaigwu SE, Alimi LO, et al. Synthesis of zinc-carboxylate metal-organic frameworks for the removal of emerging drug contaminant (amodiaquine) from aqueous solution. Journal of Environmental Sciences. 2018 Feb;64:264-75.

22. Jimoh $\mathrm{T}$, Buoro A, Muriana M. Utilization of Blighia sapida (Akee apple) pod in the removal of lead, cadmium and cobalt ions from aqueous solution. JECE. 2012 Jul;4(10):178-87.

23. Afkhami A, Saber-Tehrani M, Bagheri H. Simultaneous removal of heavy-metal ions in wastewater samples using nano-alumina modified with 2,4-dinitrophenylhydrazine. Journal of Hazardous Materials. 2010 Sep;181(1-3):83644.

24. Shooto N, Dikio E, Wankasi D, SIKHWIVHILU L. Synthesis, Morphology and Lead Ion Adsorption Properties of Metal Organic Frameworks of Copper and Cobalt. CSJ. 2015;6(4):1000113.

25. Barka N, Ouzaouit K, Abdennouri M, Makhfouk ME. Dried prickly pear cactus (Opuntia ficus indica) cladodes as a low-cost and eco-friendly biosorbent for dyes removal from aqueous solutions. Journal of the Taiwan Institute of Chemical Engineers. 2013 Jan;44(1):52-60.

26. Ajmal M, Rao RAK, Ahmad R, Ahmad J. Adsorption studies on Citrus reticulata (fruit peel of orange): removal and recovery of $\mathrm{Ni}$ (II) from electroplating wastewater. Journal of Hazardous Materials. 2000 Dec;79(1-2):11731.

27. Demirbas E, Kobya M, Konukman AES. Error analysis of equilibrium studies for the almond shell activated carbon adsorption of $\mathrm{Cr}(\mathrm{VI})$ from aqueous solutions. Journal of Hazardous Materials. 2008 Jun;154(1-3):78794.

28. Okoli I. Adsorption Studies of Heavy Metals by LowCost Adsorbents. JASEM. 2014;18(3):443-8.

29. Dikio E, Farah A. Synthesis, Characterization and Comparative Study of Copper and Zinc Metal Organic Frameworks. Chemical Science Transactions. 2013 Oct $4 ; 2(4): 1386-94$.

30. Wu Y, Zhang B, Li F, Zhu W, Xu D, Hannam P, et al. Electrospun fibrous mats as a skeleton for fabricating hierarchically structured materials as sorbents for $\mathrm{Cu} 2+$. Journal of Materials Chemistry. 2012;22(11):5089 
